ELORE (ISSN 1456-3010), vol. $12-2 / 2005$.

Julkaisija: Suomen Kansantietouden Tutkijain Seura ry. Taitto: Jukka Talve ja Outi Fingerroos.

[http://cc.joensuu.fi/ /oristi/2_05/mah2_05.pdf]

\title{
KIRJA-ARVIO:
}

\section{TUNTEMATTOMALLE TUTKIJALLE}

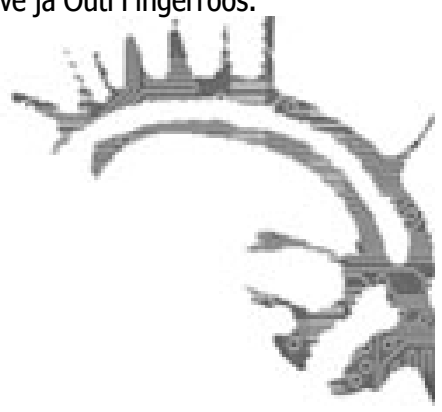

Tuulike. Kurki (toim.) 2004: Kansanrunousarkisto, lukijatja tulkinnat. Suomalaisen Kirjallisunden Seuran Toimituksia 1002. Helsinki: Suomalaisen Kirjallisunden Seura, 273 s.

Tiina Mahlamäki

Kenttätyöhön liittyvät kysymykset ovat viime aikoina kirjoituttaneet kulttuurien tutkijoita, esimerkiksi Kalevala-seuran vuosikirjoissa Tutkijat kentällä (2003) ja Kenttäkysymyksiä (2004). Kentältä on siirrytty arkistoon Tuulikki Kurjen toimittamassa artikkelikokoelmassa, jossa folkloristit, uskontotieteilijät ja kulttuurien tutkijat pohtivat Kansanrunousarkiston aineistojen äärellä erilaisia tutkimusaineistojen käyttöön liittyviä teoreettisia ja metodologisia kysymyksiä. Teos jakautuu kahteen, keskenään dialogiseen osaan, joiden esitysjärjestys olisi voinut olla toisenlainenkin. Kokoelman alkuosassa nuoret, juuri väitelleet tai lähitulevaisuudessa väittelevät tutkijat problematisoivat henkilökohtaista suhtautumistaan, kokemistaan ja tuntemistaan aineistojen parissa. Tutkimusprosessi näyttäytyy monelle heistä osana omaa henkilökohtaista kasvua valmiiksi tutkijaksi. Osana tätä prosessia he myös kirjoittautuvat sisään tutkimusraportteihin ja käsillä oleviin artikkeleihin. Loppupään kokeneemmat, monenlaisia arkistoja, aineistoja sekä teorioiden ja metodien tuloja ja menoja nähneet tutkijat taas tuovat esille kokonaisen tieteenalan ja tiedekäsityksen kasvun, kehityksen ja muutoksen prosesseja.

Artikkelikokoelmaan tutustuessa selviää (viimeistään!) Kansanrunousarkiston aineistojen ainutlaatuisuus, monipuolisuus ja monikäyttöisyys. Ongelmia tai haasteellisuutta tuottavat sen sijaan, varsinkin vanhempien aineistoryhmien kohdalla, erilaiset seulat, hyvän kertojan ideaalit sekä joustamattomat luokittelujärjestelmät. Tämän päivän kulttuurien tutkijoita pohdituttavat oma paikka ja rooli tutkijana sekä aineistojen ja lukutapojen kontekstualisointi. Kiinnostuksen kohteet löytyvät marginaaleista, luokitusten väleistä ja aineistojen tarjoamista heikoista signaaleista.

Tarkastellessani tätä teosta näkökulmani on perinnearkiston työntekijän, minkä vuoksi teoreettiset kysymykset ja perinnetieteiden tutkimusperinteen kehitys jäävät paljolti sivuun. Sen sijaan pohdin tarkemmin muutamaa artikkelikokoelmasta nousevaa keskeistä teemaa: paikantumista, konteksteja, marginaaleja, dialogisuutta sekä kansan käsitettä. 


\section{Paikantumisen pakko}

Feministisestä tutkimusotteesta tuttu paikantuminen alkaa olla keskeinen osa kulttuurien tutkijankin tutkimusprosessia. Paikantumista tarvitaan, jotta pystytään tiedostamaan oma, subjektiivinen, osittainen ja näkökulmainen lukutapa. Tarvitaan myös aineiston paikantamista sekä aineiston takana puhuvan perinteenkantajan paikantamista. Tutkijoita on usein syytetty paikantumisen mekanistisuudesta, sen irrallisuudesta itse tutkimusprosessista. Paikantumisen tulisikin tapahtua läpi koko tutkimuksenteon ja siitä raportoinnin. Lisäksi siihen tulisi liittyä myös sitoumuksien aukikirjoittaminen.

Paikantumisen ja reflektoinnin merkittävyys ja keskeisyys, sen kietoutuneisuus elimelliseksi osaksi tutkimusprosessia, tulee hyvin esiin käsillä olevan artikkelikokoelman teksteistä. Teoksen aloittava Outi Fingerroos paikantaa itsensä tuoreeksi tohtoriksi, mutta tuo myös kiintoisasti ja avoimesti esiin sitoutumisensa ja kirjoittamisen agendansa. Hän haluaa nostaa esiin vaietut tarinat ja punaisten muistot vuoden 1918 tapahtumista Viipurissa. Paikantuminen on jopa niin konkreettista, että Fingerroos asettaa itsensä tietyn puun juurelle, paikkaan johon hän kietoo tarinansa ja tulkintansa teloitetusta tytöstä. Teemu Taira taas pysyttäytyy tiukan teoreettis-metodologisessa paikantamisessa, johon hänen kirjoittamisen agendansakin liittyy. Taira haluaa tuoda brittiläisen kulttuurintutkimuksen lähestymistapoja ja käsitteitä suomalaiseen uskontotieteeseen ja kulttuurien tutkimukseen. Myös Pauliina Latvala ja Mari Hatakka kirjoittautuvat osaksi tutkimusprosessia ja tuovat esiin henkilökohtaisten mieltymysten, ennakkoasenteiden ja elämänkokemusten merkityksen aineistoja lähestyttäessä ja analysoitaessa. Henkilökohtaiset elementit ovat aina tutkimusprosessissa läsnä, mutta kaikki tutkijat eivät niitä tule tiedostaneeksi tai aukikirjoittaneeksi.

\section{SOPIMATTOMAT AINEISTOT JA INFORMANTIT}

Perinteenkantaja näyttää vanhaa aineistoa kerättäessä olleen todellakin kantaja: eräänlainen astia, joka on samaan aikaan sekä iäkäs että luotettava ja josta on ammennettu yhdelle arkistokortille sopivasti mahtuvina palasina uskomuksia, taikoja ja sananparsia. Nämä perinteenkappaleet on uskollinen kerääjä kirjoittanut tarkasti ylös, välttäen tuomasta esiin omia tulkintojaan, ja lähettänyt arvoisille tutkijoille kansanrunousarkistoon. Tutkijat taas ovat arvioineet kerääjän hyväksi tai huonoksi, hartaaksi tai "omiaan sepitteleväksi" - ja näiden arvioiden mukaan aineisto on päässyt arkistolaatikoihin tai siirretty vähän sivumpaan epämääräisenä tai epäluotettavana. Näiden syrjäänjätettyjen ja marginaaliin pudotettujen tekstien arvo on nykypäivän tutkijalle aivan erilainen, kuten Tuulikki Kurki artikkelissaan osoittaa.

Touko Issakainen, kuten useat muutkin kokoelman kirjoittajista, puhuu huonoiksi määritellyistä perinteistä, kerääjistä ja kertojista. Ainakin aiempaa - todennäköisesti myös nykyistä, vaikka tupakkalämpiötä ei varmaankaan enää ole - 
tutkijoiden sisäpiiritietoa ovat olleet näkemykset kertojien ja kerääjien ominaisuuksista ja omituisuuksista sekä heidän aineistojensa käyttökelpoisuudesta. En ollenkaan ihmettele, että nykytutkija tuntee viehtymystä tarkastella väheksyttyjä tai hyljeksittyjä aineistoja, tutustua hankaliksi ja epäluotettaviksi nimettyihin henkilöihin (jollaiseksi Kurjenkin tutkima Heikki Meriläinen määrittyi) ja selailla kortteja, joissa varoitetaan: "Cave!"

\section{VÄÄRIN LUETTELOITU?}

Arkistoihin kertyvä aineisto on luonnollisesti luokiteltava ja luetteloitava jollakin systemaattisella tavalla, jotta sen käyttö tutkimuksessa mahdollistuisi. Artikkelikokoelma tuo näkyviin tuon arkistointiprosessin subjektiivisuuden, valikoivuuden ja jopa suoranaisen sensuroinnin - vaikka niistä ei arkisto-oppaissa tai ensivuoden opiskelijoille ensimmäiseksi mainitakaan. Sekä Kaarina Koski että Touko Issakainen tarkastelevat Kansanrunousarkiston niin sanottua vanhaa aineistoa, ja pohtivat molemmat uskomustarinoiden luokittelujen ongelmia. Nykypäivän tutkimusongelmien vaatimat aineistokokonaisuudet poikkeavat suuresti niistä historiallismaantieteellisistä lähtökohdista, joiden pohjalle arkiston luokitusjärjestelmä on rakennettu. Tämän vuoksi haluttu aineisto on kaivettava kortistojen väleistä ja yritettävä jotenkin ylittää se kuilu, joka aineiston keruu- ja tutkimuskontekstien väliin auttamatta syntyy. Aineistoja voi myös yhdistellä uusin tavoin, jolloin ne tarjoavat uudenlaisen näkökulman tutkittavaan aiheeseen tai kokonaan uudenlaisen kokonaisuuden, tulkinnallisen maailman, kuten Tuulikki Kurki artikkelissaan osoittaa. Toisaalta keruukonteksti ja siihen liittyvät luokittelun ja luetteloinnin tavat myös rajaavat mahdollisia tutkimuskysymyksiä. Aineistolta ei voi kysyä kaikkia tämän päivän kulttuurientutkijaa kiinnostavia kysymyksiä. Koski kuitenkin yrittää tätä tulkitessaan aineistoa toisin kuin se on luokiteltu. Onko tämä eräänlaista feministisestä kirjallisuudentutkimuksesta tuttua vastakarvaan lukemista, vastustavaa lukemista?

Arkistotutkijan on kuitenkin opittava elämään aiempien arkistojärjestelmien kanssa. Tutkijan on hyväksyttävä se, että arkistokonteksti suodattaa aineistoihin merkityksiä eikä mikään luokitteluperuste tai -järjestelmä ole hyvä kaikkiin tarkoituksiin. Ei edes digitointi, vaikka sitä tarjotaankin lääkkeeksi moneen ongelmaan. Jäykkiä luokittelujärjestelmiä ei kannata siunailla vaan vaihtaa näkökulmaa, kuten Issakainen ehdottaa, tai nähdä luokittelu omaan aikaansa sidoksissa olevana tulkintana, joka taas on Kosken lähestymistapa. Aineisto on joka tapauksessa monin tavoin suodattunut, eikä tuota suodattumista pidä aina nähdä pelkästään negatiivisena.

Arkistoaineistoa tulkitsevissa tutkimuksissa jää usein vähemmälle huomiolle arkistohenkilökunnan rooli sekä arkistointiprosessin subjektiivisuus. Pauliina Latvala avaa artikkelissaan tätäkin puolta tarjoamalla kiinnostavan omakohtaisen aineiston kuvailun reflektoinnin. Hän pohtii tärkeästi ja ajatuksia herättävästi omaa paikantumisen prosessiaan Suvun suuri kertomus -keruun vastausaineistoja luetteloidessaan. Luokittelun ongelmat tulevat esiin useassa muussakin tekstissä. Luokittelu on aina subjektiivista, vaikka se päällepäin näyttäisikin hyvin systemaattiselta. 


\section{TiINA MAHLAMÄKI}

Avain- tai asiasanat sekä aineistoa kuvaileva referaatti tai sisällysluettelo ovat niitä työkaluja, joiden avulla aineisto myöhemmin päätyy tai on päätymättä tutkimusaineistoksi. Osaavakaan informaationhaku ei tavoita aineistoja, jotka on kuvailtu huolimattomasti tai puutteellisesti. Arkistoaineistojen luetteloinnin ja kuvailun aukollisuus ja huojuvuus näkyvät tuskallisen selvästi Latvalan artikkelista, ja tämä tulisi arkistojen äärelle hakeutuvan tutkijankin muistaa.

\section{KANSA VASTAA - TUTKIJAT KYSYVÄT}

Dialogin ja dialogisuuden teema kulkee läpi käsillä olevan teoksen artikkelien. Tutkijat käyvät dialogia aineistonsa kanssa, ja pohtivat dialogisuuden mahdollisuuksia ja rajoja suhteessa aineiston taustalla häämöttäviin kertojiin. Oikean kertojan tapaaminen saattaa näyttäytyä jopa pelottavalta mahdollisuudelta. Niin perinteenkerääjien kuin kilpakirjoittajien ja muistelijoiden kohteena on ollut "tuntematon tutkija", anonyymi, kuviteltu lukija, "joku kirjailija", joka tekstin arkistosta löytää. Tätä dialogin mahdollisuutta tai mahdottomuutta usea teoksen kirjoittajista pohtiikin. Arkistossa oleva informaatio on niin välittynyttä, että dialogin toisena osapuolena on aina "vieras sana". Ulla-Maija Peltonen tarjoaa vieraan sanan kohtaamiseen dialogisen suunnistumisen menetelmää, pyrkimystä aktiiviseen ymmärtämiseen.

Peltonen tarkastelee kansanrunouden keruun ohjeistuksia, kerääjille annettuja neuvoja suullisen perinteen tallentamiseen ja muistiin kirjoittamiseen. Dialogi käytiin arkiston ja kerääjän sekä kerääjän ja perinteenkantajan välillä siten, etteivät arkisto tai tutkija ja kansa koskaan kohdanneet. Välittäjänä toimivat kerääjät, jotka saivat ohjeet ja nuhteet arkistosta. Kansa näyttää aina olevan jossain muualla, taustalla ja takana. Kiinnostava on kuitenkin Peltosen näkökulma, joka laajenee perinneaineistoista ja keruuesitteistä virka-arkistosta löytyvään arkiston ja kerääjän väliseen kirjeenvaihtoon. Tuloksena on samantapainen tulkinnallinen maailma kuin Tuulikki Kurjen artikkelissakin.

Tuulikki Kurki huomioi kaunokirjallisuuden näyttävän perinteen ristiriitaisten käsitysten kokonaisuutena, kun taas arkistoon tallennetuista keruista on kertojien moniäänisyys pyritty karsimaan - usein kerääjien toimesta, jotka arastelivat lähettää rivouksia tutkijoiden silmien alle. Kerääjät tavallaan konstruoivat yksiäänisen kansan SKS:n tutkijoiden tarpeisiin. Dialogi ei siis tässäkään kontekstissa ole väärintulkinnoista ja valta-asetelmista vapaata. Kerääjä kyselee kansalta, mitä hän olettaa Helsingin tutkijoiden kaipaavan. Ja kansa vastaa kilpakeruisiin keruuesitteen herättämien odotusten ja oletusten pohjalta. Keruuvastauksissa näkyykin selkeästi vastaajan näkemys arkistosta ja sen odotuksista.

Kun kerääjien käytöstä siirryttiin (kansan luku- ja kirjoitustaidon kasvaessa?) vastaajaverkoston käyttöön ja kilpakeruisiin, näyttää yllättävästi siltä, että kansa vaikeni edelleen. Kansan ajatuksia välittivät oppineet, sivistyneet ja koulutetut sekä myöhemmin kansan jälkeläiset. Pauliina Latvalan (s. 143) sanoin: "[A]ikaisemmin kansa kirjoitti arkistoon omasta elämänpiiristään. Tänä päivänä enemmis- 
tönä on toinen sukupolvi, 'kansan' eri-ikäiset jälkeläiset, jotka pikemminkin kirjoittavat käsityksiään kansasta kuin ovat osa sitä.” Kansa jää jopa Kansanrunousarkistossa jonnekin muualle, taustalle ja ilman omaa ääntään.

Kansa koostuu kuitenkin henkilöistä, miehistä ja naisista, joita koskevaa tietoa on arkistoon tallennettu aiemmin vähemmän ja nykyisin enemmän systemaattisesti. Senni Timonen ja Jyrki Pöysä käsittelevät artikkelissaan elämäkerrallisten tietojen kehittymistä ja sitä, miten perinteenkantajien yksilöllisyydestä ja elämäkerroista alettiin tutkimus- ja arkistointimielessä vähä vähältä kiinnostua. He puuttuvat myös tärkeään ongelmaan: informanttien yksityisyyden suojaan, johon on aiemmin - tieteen ja tutkimuksen nimissä - suhtauduttu melko leväperäisesti. Kerääjät ovat toisaalta kaivaneet haastateltaviltaan tietoja heidän yksityiselämästään ja toisaalta arvioineet heidän persoonallisuuttaan tavoilla, jotka eivät tänään tulisi kuuloonkaan. Kilpakeruisiin kirjoittajille on vasta 1980-luvun alusta asti tarjottu mahdollisuutta vastata anonyymeinä, koska keruiden aiheet ovat koskeneet yhä yksityisempiä asioita. Pöysä ja Timonen kysyvätkin, onko yleinen arkisto oikea paikka säilyttää keruiden myötä kertynyttä hyvin henkilökohtaista tietoa. Ainutlaatuista aineistoa olisi tuhlaus hävittääkään, joten arkaluontoisia teemoja käsittelevien aineistojen anonymisointia olisi syytä harkita.

\section{TUNTEVA TUTKIJA - ELÄMYKSIÄ ARKISTOSSA}

Vaietuiksi eivät joudu vain tietyt aineistot, perinnelajit tai perinteenkantajat. Myös tutkimusprosesseissa on tiettyjä vaiheita tai ulottuvuuksia, joita ei useinkaan tutkimuskirjallisuudessa käsitellä. Mari Hatakka tekeekin artikkelissaan tärkeän huomion: "Emotionaaliset reaktiot aineistoihin, lukemiseen ja muihin tutkimusvaiheisiin ovat folkloristien omaa suullista perinnettä” (s. 176). Tämän perinteen hän soisi tallentuvan myös jälkipolville. Tunteistahan puhutaan yleensä vain kenttätyökokemusten yhteydessä, eikä aina silloinkaan. Tämän artikkelikokoelman keskiosan tutkijat paljastuvat ihmisiksi: tunteviksi, kokeviksi ja kehittyviksi - samaan tapaan kuin kertojat paljastuvat vähitellen muisteleviksi, kokeviksi, tuottaviksi yksilöiksi. Kertojien ja kerääjien tarkoitusperät nähdään joskus epäilyttäviksi, he haluavat pelkästään rahaa, palkintoja tai nimensä julkaisuihin.

Myös tämän teoksen kirjoittajilla on omia tarkoitusperiään, kuten nostaa esiin marginaaleihin pudonneet tai pudotetut ja antaa puheenvuoro vaienneille tai vaiennetuille. Tarkoitusperien mahdollinen subjektiivisuus ei tee niistä epätieteellisiä, ainakaan tässä kokoelmassa. Itse olen usein ihmetellyt ja ihaillut, miten vaikeita, traumaattisia ja kipeitä aiheita tarkastelevat tutkijat kestävät aineistojensa äärellä. Ehkä he eivät aina kestä, eikä tarvitsekaan. Onneksi aineistoista voi aina irtautua ja lähteä ruokatunnille - vaikka syyllisyyttä tuntisikin. 


\section{MITÄ OPIMME TÄSTÄ?}

Tuulikki Kurki tiivistää mielestäni hienosti tämän artikkelikokoelman keskeisen sanoman: "Kansanrunousarkiston liepeille ja välimaastoon sijoitettujen tekstien merkitys ilmenee myös siten, että näkökulman voi suunnata myös niistä kohti Kansanrunousarkistoa ja oppineiston kirjallista kulttuuria. Tekstejä on näin mahdollista käyttää eräänlaisena negatiivisen tiedon lähteenä, jolloin ilmenee se, millaiset esitykset ovat vakiintuneet suhteellisen objektiivisiksi koetuiksi käsityksiksi perinteestä ja kansasta, ja kuinka tallennettavaksi kelpaavan perinteen kriteerit ovat vaihdelleet." (S. 83). Katseen ei tällöin tarvitsekaan hamuilla kohti kansaa, vaan Kansanrunousarkisto voidaan nähdä kokoelmana, joka on syntynyt oppineiston kansaan kohdistamien odotuksien ja toiveiden tuloksena.

Nuoret tutkijat suhtautuvat tämän teoksen perusteella erittäin varovasti yleistyksiin kansasta tai jostain sen osasta. Myös kömpelöitä luokitusjärjestelmiä rakennelleisiin ja kerääjille isällisen nuhtelevia kirjeitä lähetelleisiin arkistotutkijoihin suhtaudutaan lempeän ymmärtäväisesti. Artikkelikokoelmassa keskitytään toisaalta niin sanottuun vanhaan, kerääjien kertojilta keräämään ja sittemmin laatikoihin lajiteltuun perinteeseen, toisaalta kilpakeruiden ja vastaajaverkoston tuottamaan aineistoon. Jäin vielä kaipaamaan kolmatta aineistoluokkaa (jota vain ohimennen sivuttiin): haastatteluaineistoja ja niiden tulkinnan analyysia. Erityisen kiinnostavaa olisi perehtyä 1950-1960-lukujen aikaan, jolloin nauhurien käyttö haastatteluissa yleistyi. Millaista aineistoa kertyi, kun äänitysstudio pystytettiin kyläkoululle ja sinne pyydettiin kylän ansiokkaat perinteenkantajat esiintymään? Kalliille kelanauhoille säästettiin vain parhaat palat eli suodatin toimi myös tässä kontekstissa. Avokelojen aarteet odottavat vielä tutkimushistoriallista tarkasteluaan.

\section{LÄHTEET}

LAAKSONEN, PEKKA \& KNUUTTILA, SEPPO \& PIELA, ULLA (toim.) 2003: Tutkijat kentällä. Kalevalaseuran vuosikirja 82. Helsinki: Suomalaisen Kirjallisuuden Seura.

LAAKSONEN, PEKKA \& KNUUTTILA, SEPPO \& PIELA, ULLA (toim.) 2004: Kenttäkysymyksiä. Kalevalaseuran vuosikirja 83. Helsinki: Suomalaisen Kirjallisuuden Seura.

FM Tiina Mahlamäki on uskontotieteen assistentti ja TKU-kokoelman arkistovastaava Turun yliopiston kulttuurien tutkimuksen laitoksella. 